\title{
A REVIEW OF NEUROPHYSIOLOGICAL AND GENETIC CORRELATES OF EMOTIONAL INTELLIGENCE
}

Dr. Kosonogov Vla
Dr. Vorobyeva Elena, Don State
Dr. Kovsh Ekaterina, Southern Fed Dr. Ermakov Pave
A R T I C L E O
Review Article
Received: November, 17.2018.
Revised: February, 20.2019.
Accepted: March, 03.2019.
doi:10.5937/ijcrsee1901137K
UDK
159.942.072
159.922.072

Keywords:

emotional intelligence,

neural correlates,

$E E G$,

behavior genetics,

brain,

neurotransmitters.

\begin{abstract}
A B S T R A C T
The article is an overview of modern studies of brain organization and genetic correlates of emotional intelligence. Emotional intelligence is becoming the subject of more and more attentive study of psychologists due to the fact that it influences the mental development of humans, plays an important role in many professions, and its impairment is a marker of some disorders. Nevertheless, the brain organization and genetic correlates of emotional intelligence have not been studied enough - first studies appeared only in the early 2000s. A review of the literature on the encephalographic showed that in rest, people with higher emotional intelligence show greater excitation of the left anterior regions of the brain. When perceiving affective stimuli, participants with high emotional intelligence show stronger synchronization of some EEG rhythms. Brain mapping technique made it possible to identify the areas of the brain involved in activities related to emotional intelligence. In regard to genetic correlates of emotional intelligence, some genes of neurotransmitter systems have been associated to this trait: the catechol-O-methyltransferase gene COMT, the dopamine $\mathrm{DRD} 2$ receptor gene, the serotonin receptor gene HTR2A, and the BDNF brain neurotrophic factor gene.
\end{abstract}

(C) 2019 IJCRSEE. All rights reserved.

\section{INTRODUCTION}

Emotional intelligence is an ability to process emotional information, including recognition of one's own emotions and emotions of other people, expression of emotions and adaptive regulation of emotions, which ultimately provides a more effective solution of applied life problems (Mayer, DiPaolo and Salovey, 1990). Nowadays the concept of "emotional intelligence" is widely used in applied research (engineering psychology, developmental psychology, psychiatry, behavioral economics, family psychology etc.) For

Corresponding Author

Dr. Kosonogov Vladimir, Southern Federal University, Russian Federation

E-mail: vkosonogov@sfedu.ru

\section{(c) (i) $\odot$}

This work is licensed under a Creative Commons Attribution - NonCommercial - NoDerivs 4.0. The article is published with Open Access at www.ijcrsee.com example, patients with depression have low rates of emotional intelligence (Downey et al., 2008), and teachers with low emotional intelligence have higher probability of professional burnout (Pishghadam and Sahebjam, 2012). However, only now scholars begin studying the neurophysiological and genetic correlates of emotional intelligence.

Jaušovec and coworkers (Jaušovec, Jaušovec and Gerlič, 2001), perhaps, was the first to study emotional intelligence using the method of electroencephalography (EEG); they found a slight desynchronization of the alpha rhythm and a large synchronization of the theta rhythm in the left hemisphere in participants with a high level of emotional intelligence. Kemp and colleagues (Kemp et al., 2005) revealed interhemispheric asymmetry associated with emotional intelligence, namely, excitation of the left frontal regions was higher at rest in individuals with high emotional intelligence; although in a later study in children no such results were found (Santesso, Dana, Schmidt and Segalowitz, 2006). Later, 
Mikolajczak and colleagues (Mikolajczak, et all, 2010) confirmed that the excitation of the left frontal regions at rest is higher in partiticipants with the higher level of emotional intelligence. Freudenthaler, Fink and Neubauer (2006), in turn, found a larger amount of event-related desynchronization in participants with interpersonal low emotional management abilities in both sexes.

There are also few studies of neural underpinnings of emotional intelligence with the use of various stimuli. Jaušovec and Jaušovec (2005) found a high synchronization of the EEG gamma rhythm and low desynchronization of the EEG alpha rhythm in participants with high emotional intelligence during pictures with people expressing different emotions. Kniazev and colleagues (Kniazev, Mitrofanova and Bocharov, 2013), presenting angry and happy faces, revealed a high synchronization of tetha rhythm in the first 500 $\mathrm{ms}$ in participants with high emotional intelligence; and the analysis of the activity after $500 \mathrm{~ms}$ showed that synchronization of the theta rhythm of the EEG in the left frontal areas was higher during the perception of happy faces in participants with high emotional intelligence. Raz et all, (2013) recorded eventrelated potentials during watching affective pictures and revealed that participants with high emotional intelligence exhibited significantly greater $\mathrm{P} 2$ and $\mathrm{P} 3$ mean amplitudes at posterior-parietal and frontal scalp locations than participants with low emotional intelligence. Rusalova's laboratory, in turn, conducted several electroen-cephalographic studies of vocal emotion recognition and revealed a large initial (base-line or at rest) activation, as well as a higher level of local activation of the posterior temporal cortex of the right hemisphere and the anterior parts of the left hemisphere in the recognition of emotions in participants with low rates of vocal emotion recognition (Kislova and Rusalova, 2008; Kislova and Rusalova, 2009; Rusalova, Kislova and Sidorova, 2010). Brain mapping with different types of tomography in participants with brain diseases and emotional intelligence impairment allowed to identify the following brain areas associated with emotional intelligence: left posterior temporal cortex, left posterior superior temporal sulcus, left temporoparietal junction, left orbitofrontal cortex, left anterior cingulate cortex, anterior insula (Barbie, Colom, and Grafman, 2012). Earlier studies also found the influence of limbic areas, cerebellum, visual cortex (Killgore and YurgelunTodd, 2007) and dorsolateral frontal cortex
(Krueger et al., 2009) on emotional intelligence. Studies of emotion recognition in participants with brain lesions suggest that lesions in the right hemisphere lead to impaired recognition of emotions from speech (Heilman, Scholes, and Watson, 1975; Kucharska-Pietura, Phillips, Gernand and David, 2003; Ross, 1981; Wunderlich, Ziegler and Geigenberger, 2003); however, lesions of the left hemisphere can also lead to a decrease in recognition of emotions from speech (Kucharska-Pietura et al., 2003, Seron X., van der Kaa M.A. and van der Linden, 1982).

Regarding the study of emotional intelligence in other species, we can mention the studies of the instrumental reaction to the release of pain of others. When a subject pushes a lever, another animal ceases to feel pain, that is a reinforcement for the subject animal. In dogs and rats, about $30 \%$ of individuals are capable of such empathy. The study of morphological structures, possibly taking part in the reaction of such emotional resonance, found that bilateral destruction of the hippocampus does not have any significant effect on this behavior. Destruction of the amygdala and hypothalamus led to the opposite results. Destruction of the cingular cortex improved this reaction; however, destruction of the periaqueductal gray worsened this instrumental reaction in rats during painful stimulation of another individual (Simonov, Pigareva and Brazovskaya, 1978).

Further studies of the brain correlates of emotional intelligence, in our opinion, will be focused on the identification of areas that is responsible for various components of emotional intelligence (recognition and use of one's own and other people's emotions), as well as on the study of the impact of different areas of the brain on activities that require a high level of emotional intelligence.

The analysis of modern studies of the genetic correlates of emotional intelligence shows the lack of the sufficient number of studies aimed at studying the molecular genetic prerequisites of emotional intelligence, although the formulation of the question of the genetic factors of the ability to recognise emotions is not new and goes back to the works of Charles Darwin (Alfimova, 2016).

Several papers postulate that emotional intelligence is a complex phenomenon that is the result of a complex genotype-environmental interaction. Genealogical and twin studies conclude that emotional intelligence probably is inherited via mechanisms like the other personal traits (Vernon, Petrides, Bratko and 
Schermer, 2008).

Since environmental conditions differ for representatives of different ethnic groups, the frequency of polymorphic variants of genes associated with psychological characteristics (including emotional intelligence) should be different for different populations. Thus, there is evidence of ethnic differences in the various components of emotional intelligence (Naimanova and Adushinova, 2017). The effectiveness of the recognition of basic emotions is different in carriers of different ethnic groups as well (Karabuschenko and Khvorova, 2017).

The literature also broadly presents the results of the study of molecular genetic basis of psychological characteristics associated with emotional intelligence (neuroticism (Nagel et al., 2017), propensity to leadership and other characteristics (Forero, Pereira-Morales and González-Giraldo, 2016). However, the molecular genetic basis of emotional intelligence has not been studied yet. Nevertheless, clinical studies in schizophrenia patients have shown an association of the ability to correctly recognize emotions and the gene of the serotonin transporter SLC6A4 (Alfimova, 2016).

The association of neurotransmitter systems with human emotional reactions (Iumatov, 1995) suggests an association between the genes of neurotransmitter systems and indicators of emotional intelligence. These genes are the gene of catechol-o-methyltransferase COMT, the gene of dopamine receptor DRD2, the gene of serotonin receptor HTR2A, and the gene of neurotrophic factor of the brain BDNF, associated with the development of hippocampal neurons, cortex and anterior brain (Mandel, Ozdener and Utermohlen, 2009). These genes take an active part in providing neuroplasticity (Popova, Ilchibaeva and Naumenko, 2017) which can be associated with emotional intelligence.

It is known that the gene of catecholo-methyltransferase COMT is associated with the brain dopamine system. In the work of Goya and coworkers (Gohier et al., 2014) women, carriers of the polymorphism val158 met of the gene COMT, were asked to solve a computerised task on recognition of facial expressions, which included a distinction between neutral faces and faces expressing emotions (fear, anger, sadness and happiness). It was found that the carriers of Met allele homozygotes of COMT gene were more inclined to recognise neutral facial expressions as angry compared to the carriers of Val allele homozygotes of COMT gene.
Lin and colleagues (Lin et al., 2013) found that the carriers of Met allele of the COMT gene are better than the carriers of the Val allele in differentiating expressions of emotions.

In clinical studies (Schneider et al., 2012) in a sample of patients with a deletion chromosome 22 (a neurogenetic disease associated with a high risk of schizophrenia), it was found that a more pronounced decrease in motivation was observed in the carriers of the Met allele of the COMT gene. Homozygous carriers of the Met allele, according to another study (Thompson et al., 2012), have an increased risk of behavioral and emotional problems at the age of 7 and 11 years compared to heterozygous or homozygous carriers of Val158Met polymorphism, but only if they were subjected to prenatal stress and were born with reduced body weight.

In the work of Williams and co-workers (Williams et al., 2010) the effect of the polymorphism Valte8/158 Met of catecholo-methyltransferase of the COMT gene (that is involved in dopamine and norepi-nephrine catabolism) on the emotional function of the brain and on the predisposition to recognise negative emotions in the expressions of happiness and fear. According to fMRI data, the presence of Met allele of COMT gene is associated with an increased activation of the brain stem, amygdala, basal ganglia and medial prefrontal areas during recognition of fear and with a reduced activation of these areas during recognition of happiness.

Dopamine receptor gene DRD2. In a study carried out by Blasi and co-workers (Blasi et al., 2009) studied the association of the DRD2 rs1076560 genotype with emotional stability, and physiology of the brain during perception of affective stimuli. It was found that in healthy carriers of the genotype GG emotional control was reduced in comparison with the carriers of heterozygous genotype. They also found that amygdala, dorsolateral prefrontal areas and medial pre-frontal areas took part in the facial emotional recognition.

Alfimova and co-workers (Alfimova et al., 2017) found the participation of DRD2 gene polymorphisms in emotion recognition in schizophrenics. However, the worst result of emotion recognition was observed in patients with the minor allele of dopamine receptor DRD2 gene in combination with the minor allele of the GRIN2B gene.

In the work of Gadow and employees (Gadow, et al., 2014), it was shown that dopaminergic system genes, including DRD2, 
are associated with symptoms of emotional dysfunction, and attention deficit/hyperactivity disorder in children with autism spectrum disorder (ASD).

Gene of brain neurotrophic factor BDNF. Koven and Demers (Koven and Demers, 2014) shows the association of genes of neurotrophic factor of the brain (BDNF) and serotonin (5-HT) with emotional intelligence measured by the test of Mayer, Salovey and Caruso in healthy adult men.

Lau and coworkers (Lau et al., 2010) investigated the relationship between the genotype of BDNF gene and the accuracy of recognition of fear, anger, happiness and neutral expression in adolescents with anxiety and depression disorders and the control group of healthy adolescents with simultaneous magnetic resonance imaging. It was found that the carriers of the Met allele of the BDNF gene demonstrated a more pronounced activation of the amygdala and hippocampus during recognition of emotional faces than the carriers of the Val / Val homozygotes. These data show the contribution of BDNF gene variants to the brain correlates of adolescent anxiety and depression.

\section{CONCLUSION}

Thus, the genes of neurotransmitter systems, such as the gene of catechol-o-methyltransferase COMT, the gene of dopamine receptor DRD2, the gene of serotonin receptor HTR2A, as well as the gene of neurotrophic factor BDNF can be considered a genetic basis associated with emotional intelligence due to their influence on the features of information processing by the limbic, striopallidary systems and prefrontal cortex regions, and also because of their connection with the duration, intensity, stability and sign of emotional reactions.

It is interesting and relevant to study the distribution of alleles of these genes in carriers from different ethnic groups, in combination with a psychophysiological study on the registration of electrical activity of the brain in the recognition of emotional faces. This would help defining the prerequisites for understanding ethnic differences associated with emotional intelligence.

To solve this problem, in our opinion, it is appropriate to use the method of recording the electrical brain potentials of people of different nationalities, carriers of various genotypes of the COMT, DRD2, HTR2A, BDNF genes, while they are solving tasks, associated with recognizing facial expression, and during the search for solutions to problems with a difficult emotional context ("What does a person feel in a difficult situation?", etc.). This scenario of the experiment will allow evaluating the success of emotion recognition expressed by actors of different nationalities, as well as revealing electro-physiological and genetic markers associated with various levels of emotional intelligence in people of different nationalities.

\section{ACKNOWLEDGEMENTS}

The reported study was supported by Russian Foundation for Basic Research (RFBR), research project No. 18-013-01019.

\section{Conflict of interests}

The authors declare no conflict of interest.

\section{REFERENCES}

Alfimova M. V. (2016). Emotion recognition: Genes and experience. Priroda, 3, 11-16.

Alfimova, M. V., Golimbet, V. E., Korovaitseva, G. I., Lezheiko, T. V., Tikhonov, D. V., Ganisheva, T. K., .. \& Shemiakina, T. K. (2017). A role of interactions between N-methyl-D-aspartate and dopamine receptors in facial emotion recognition impairment in schizophrenia. Zhurnal nevrologii $i$ psikhiatrii imeni SS Korsakova, 117(6), 47-52. https://doi.org/10.17116/jnevro20171176147-52

Barbey, A. K., Colom, R., \& Grafman, J. (2012). Distributed neural system for emotional intelligence revealed by lesion mapping. Social cognitive and affective neuroscience, 9(3), 265-272. https://doi.org/10.1093/scan/nss124

Blasi, G., Bianco, L. L., Taurisano, P., Gelao, B., Romano, R., Fazio, L., ... \& Masellis, R. (2009). Functional variation of the dopamine D2 receptor gene is associated with emotional control as well as brain activity and connectivity during emotion processing in humans. Journal of Neuroscience, 29(47), 14812-14819. https://doi. org/10.1523/JNEUROSCI.3609-09.2009

Downey, L. A., Johnston, P. J., Hansen, K., Schembri, R., Stough, C., Tuckwell, V., \& Schweitzer, I. (2008). The relationship between emotional intelligence and depression in a clinical sample. The European Journal of Psychiatry, 22(2), 9398. http://scielo.isciii.es/pdf/ejpen/v22n2/original5.pdf

Forero D.A., Pereira-Morales A.J., González-Giraldo Y. (2016). Molecular Genetics and Human Behavior. In Reference Module in Neuroscience and Biobehavioral Psychology. https://doi. org/10.1016/b978-0-12-809324-5.06489-0

Freudenthaler, H. H., Fink, A., \& Neubauer, A. C. (2006). Emotional abilities and cortical acti- 
vation during emotional information processing. Personality and Individual Differences, 41(4), 685-695. https://doi.org/10.1016/j. paid.2006.02.016

Gadow, K. D., Pinsonneault, J. K., Perlman, G., \& Sadee, W. (2014). Association of dopamine gene variants, emotion dysregulation and ADHD in autism spectrum disorder. Research in developmental disabilities, 35(7), 1658-1665. https:// doi.org/10.1016/j.ridd.2014.04.007

Gohier, B., Senior, C., Radua, J., El-Hage, W., Reichenberg, A., Proitsi, P., ... \& Surguladze, S. A. (2014). Genetic modulation of the response bias towards facial displays of anger and happiness. European Psychiatry, 29(4), 197-202. https:// doi.org/10.1016/j.eurpsy.2013.03.003

Heilman, K. M., Scholes, R., \& Watson, R. T. (1975). Auditory affective agnosia. Disturbed comprehension of affective speech. Journal of Neurology, Neurosurgery \& Psychiatry, 38(1), 69-72. https://dx.doi.org/10.1136/jnnp.38.1.69

Iumatov, E. A. (1995). Neuromediator integration of emotional excitation and mechanisms of stress resistance. Vestnik Rossiiskoi akademii meditsinskikh nauk, (11), 9-16. https://europepmc.org/ abstract $/ \mathrm{med} / 8527992$

Jaušovec, N., \& Jaušovec, K. (2005). Differences in induced gamma and upper alpha oscillations in the human brain related to verbal/performance and emotional intelligence. International Journal of Psychophysiology, 56(3), 223-235. https://doi. org/10.1016/j.ijpsycho.2004.12.005

Jaušovec, N., Jaušovec, K., \& Gerlič, I. (2001). Differences in event-related and induced EEG patterns in the theta and alpha frequency bands related to human emotional intelligence. Neuroscience Letters, 311(2), 93-96. https://doi.org/10.1016/ S0304-3940(01)02141-3

Karabuschenko N. B., Khvorova E. M. (2017). Interethnic features of facial expression recognition. Vestnik Mininskogo Universiteta, 3, 14 .

Kemp, A. H., Cooper, N. J., Hermens, G., Gordon, E., Bryant, R., \& Williams, L. M. (2005). Toward an integrated profile of emotional intelligence: Introducing a brief measure. Journal of Integrative Neuroscience, 4(01), 41-61. https://doi. org/10.1142/S0219635205000677

Killgore, W. D., \& Yurgelun-Todd, D. A. (2007). Neural correlates of emotional intelligence in adolescent children. Cognitive, Affective, \& Behavioral Neuroscience, 7(2), 140-151. https://doi. org/10.3758/CABN.7.2.140

Kislova O. O., Rusalova M. N. (2009). EEG Frequency-Amplitude Characteristics of Successful Recognition of Emotion in Speech. Zh Vyssh Nerv Deiat I P Pavlova, 59, 281-288

Kislova, O. O., \& Rusalova, M. N. (2008). Correlation between the EEG coherence and recognition of emotions in speech. Rossiiskii fiziologicheskii zhurnal imeni IM Sechenova, 94(6), 650-660. https://europepmc.org/abstract/med/18727374

Kniazev, G. G., Mitrofanova, L. G., \& Bocharov, A. V. (2013). Emotional intelligence and oscillatory responses on the emotional facial expressions. Fiziologiia cheloveka, 39(4), 41-48. https://europepmc.org/abstract/med/25486829

Koven, N. S., \& Demers, L. A. (2014). Discordant peripheral levels of brain-derived neurotrophic factor and serotonin are associated with enhanced emotional intelligence in men. Psychol- ogy \& Neuroscience, 7(4), 609. https://dx.doi. org/10.3922/j.psns.2014.4.21

Krueger, F., Barbey, A. K., McCabe, K., Strenziok, M., Zamboni, G., Solomon, J., ... \& Grafman, J. (2009). The neural bases of key competencies of emotional intelligence. Proceedings of the National Academy of Sciences, 106(52), 22486-22491. https://doi.org/10.1073/ pnas.0912568106

Kucharska-Pietura, K., Phillips, M. L., Gernand, W., \& David, A. S. (2003). Perception of emotions from faces and voices following unilateral brain damage. Neuropsychologia, 41(8), 1082-1090. https://doi.org/10.1016/S0028-3932(02)002944

Lau, J. Y., Goldman, D., Buzas, B., Hodgkinson, C., Leibenluft, E., Nelson, E., ... \& Ernst, M. (2010). BDNF gene polymorphism (Val66Met) predicts amygdala and anterior hippocampus responses to emotional faces in anxious and depressed adolescents. Neuroimage, 53(3), 952-961. https:// doi.org/10.1016/j.neuroimage.2009.11.026

Lin, C. H., Tseng, Y. L., Huang, C. L., Chang, Y. C., Tsai, G. E., \& Lane, H. Y. (2013). Synergistic effects of COMT and TPH2 on social cognition. Psychiatry: Interpersonal \& Biological Processes, 76(3), 273-294. https://doi.org/10.1521/ psyc. 2013.76.3.273

Mandel, A. L., Ozdener, H., \& Utermohlen, V. (2009). Identification of pro-and mature brain-derived neurotrophic factor in human saliva. Archives of oral biology, 54(7), 689-695. https://doi. org/10.1016/j.archoralbio.2009.04.005

Mayer, J. D., DiPaolo, M., \& Salovey, P. (1990). Perceiving affective content in ambiguous visual stimuli: A component of emotional intelligence. Journal of personality assessment, 54(3-4), 772781. https://doi.org/10.1080/00223891.1990.96 74037

Mikolajczak, M., Bodarwé, K., Laloyaux, O., Hansenne, M., \& Nelis, D. (2010). Association between frontal EEG asymmetries and emotional intelligence among adults. Personality and Individual Differences, 48(2), 177-181. https://doi. $\mathrm{org} / 10.1016 /$ j.paid.2009.10.001

Nagel, M., Jansen, P. R., Stringer, S., Watanabe, K., de Leeuw, C. A., Bryois, J., ... \& Linnasrsson, S. (2017). GWAS Meta-analysis of neuroticism $(\mathrm{N}=449,484)$ identifies novel genetic loci and pathways. bioRxiv, 184820. https://doi. org/10.1101/184820

Naimanova A. V., Adushinova A. G. (2017). Features of emotional intelligence of different ethnocultures representatives. Sotsialnaia kompetentnost, 5, 51-57.

Pishghadam, R., \& Sahebjam, S. (2012). Personality and emotional intelligence in teacher burnout. The Spanish journal of psychology, 15(1), 227236. https://doi.org/10.5209/rev SJOP.2012. v15.n1.37314

Popova, N. K., Ilchibaeva, T. V., \& Naumenko, V. S. (2017). Neurotrophic Factors (BDNF and GDNF) and the Serotonergic System of the Brain. Biochemistry (Moscow), 82(3), 308-317. https://doi.org/10.1134/S0006297917030099

Raz, S., Dan, O., Arad, H., \& Zysberg, L. (2013). Behavioral and neural correlates of emotional intelligence: An Event-Related Potentials (ERP) study. Brain research, 1526, 44-53. https://doi. org/10.1016/j.brainres.2013.05.048 
Kosonogov V., Vorobyeva E., Kovsh E., Ermakov P. (2019). A review of neurophysiological and genetic correlates of emotional intelligence, International Journal of Cognitive Research in Science, Engineering and

Education (IJCRSEE), 7(1), 137-142

Ross, E. D. (1981). The aprosodias: Functional-anatomic organization of the affective components of language in the right hemisphere. $A r-$ chives of Neurology, 38(9), 561-569. https://doi. org/10.1001/archneur.1981.00510090055006

Rusalova, M. N., Kislova, O. O., \& Sidorova, O. A. (2010). Speech recognition in the norm and pathology. Rossiiskii fiziologicheskii zhurnal imeni IM Sechenova, 96(1), 3-12. https://europepmc. org/abstract/med/20297688

Santesso, L. D., Dana, L. R., Schmidt, L. A., \& Segalowitz, S. J. (2006). Frontal electroencephalogram activation asymmetry, emotional intelligence, and externalizing behaviors in 10-year-old children. Child psychiatry and human development, 36(3), 311-328. https://doi.org/10.1007/s10578005-0005-2

Schneider, M., Van der Linden, M., Glaser, B., Rizzi, E., Dahoun, S. P., Hinard, C., ... \& Eliez, S. (2012). Preliminary structure and predictive value of attenuated negative symptoms in $22 \mathrm{q} 11$. 2 deletion syndrome. Psychiatry Research, 196(2-3), 277-284. https://doi.org/10.1016/j. psychres.2011.08.017

Seron, X., Van der Kaa, M. A., Vanderlinden, M., Remits, A., \& Feyereisen, P. (1982). Decoding paralinguistic signals: effect of semantic and prosodic cues on aphasics' comprehension. Journal of Communication Disorders, 15(3), 223-231. https://doi.org/10.1016/0021-9924(82)90035-1

Simonov, P. V., Pigareva, M. L., \& Brazovskaia, F. A. (1978). Avoidance reactions to a partner's pain stimulation in rats with local brain damage. Zhurnal vysshei nervnoi deiatelnosti imeni IP Pavlova, 28(3), 514-521. https://europepmc.org/ abstract/med/676499

Thompson, J. M., SONUGA-BARKE, E. J., Morgan, A. R., Cornforth, C. M., Turic, D., Ferguson, L. R., ... \& Waldie, K. E. (2012). The catechol-O-methyltransferase (COMT) Val158Met polymorphism moderates the effect of antenatal stress on childhood behavioural problems: longitudinal evidence across multiple ages. Developmental Medicine \& Child Neurology, 54(2), 148-154. https://doi.org/10.1111/j.14698749.2011.04129.x

Vernon, P. A., Petrides, K. V., Bratko, D., \& Schermer, J. A. (2008). A behavioral genetic study of trait emotional intelligence. Emotion, 8(5), 635. https://dx.doi.org/10.1037/a0013439

Williams, L. M., Gatt, J. M., Grieve, S. M., DobsonStone, C., Paul, R. H., Gordon, E., \& Schofield, P. R. (2010). COMT Val108/158Met polymorphism effects on emotional brain function and negativity bias. Neuroimage, 53(3), 918-925. https://doi.org/10.1016/j.neuroimage.2010.01.084

Wunderlich, A., Ziegler, W., \& Geigenberger, A. (2003). Implicit processing of prosodic information in patients with left and right hemisphere stroke. Aphasiology, 17(9), 861-879. https://doi. org/10.1080/02687030344000283 